\title{
Virgibacillus salarius sp. nov., a halophilic bacterium isolated from a Saharan salt lake
}

Correspondence

Takeshi Naganuma takn@hiroshima-u.ac.jp

\author{
Ngoc-Phuc Hua, ${ }^{1}$ Amel Hamza-Chaffai, ${ }^{2}$ Russell H. Vreeland, ${ }^{3}$ \\ Hiroko Isoda ${ }^{4}$ and Takeshi Naganuma ${ }^{1,4}$
}
${ }^{1}$ Graduate School of Biosphere Science, Hiroshima University, Kagamiyama, Higashi-hiroshima 739-8528, Japan
${ }^{2}$ Unit de Recherche 09-03, Ecotoxicologie Marine, Institut Préparatoire aux Etudes d'Ingénieurs de Sfax, Université de Sfax, IPEIS BP 805, 3018 Sfax, Tunisia
${ }^{3}$ Ancient Biomaterials Institute and Department of Biology, West Chester University, West Chester, PA 19383, USA
${ }^{4}$ Alliance for Research on Northern Africa, University of Tsukuba, 1-1-1 Tennoudai, Tsukuba 305- 8572, Japan

\begin{abstract}
A Gram-positive, endospore-forming, rod-shaped and moderately halophilic bacterium was isolated from a salt-crust sample collected from Gharsa salt lake (Chott el Gharsa), Tunisia. The newly isolated bacterium, designated $\mathrm{SA}-\mathrm{Vb} 1^{\top}$, was identified based on polyphasic taxonomy including genotypic, phenotypic and chemotaxonomic characterization. Strain $\mathrm{SA}-\mathrm{Vb} 1^{\top}$ was closely related to the type strains of Virgibacillus marismortui and Virgibacillus olivae, with $16 \mathrm{~S}$ rRNA gene sequence similarities of 99.7 and $99.4 \%$, respectively. However, strain $S A-V b 1^{\top}$ was distinguished from these two type strains on the basis of phenotypic characteristics and DNADNA relatedness (29.4 and $5.1 \%$, respectively). The genetic relationship between strain $\mathrm{SA}-\mathrm{Vb} 1^{\top}$ and Virgibacillus pantothenticus IAM $11061^{\top}$ (the type strain of the type species) and other type strains of the genus was 96-98\% based on 16S rRNA gene sequence similarity and 18.3$22.3 \%$ based on DNA-DNA hybridization. Biochemical analysis resulted in determination of major fatty acids iso- $C_{15: 0}$, anteiso- $C_{15: 0}$ and anteiso- $C_{17: 0}(33.3,29.2$ and $9.8 \%$, respectively); phosphatidylglycerol, diphosphatidylglycerol and phosphatidylethanolamine were the main polar lipids and MK-7 was the predominant menaquinone ( 100\%). The distinct characteristics demonstrated by strain $\mathrm{SA}-\mathrm{Vb} 1^{\top}$ represent properties of a novel species of the genus Virgibacillus, for which the name Virgibacillus salarius sp. nov. is proposed. The type strain is $\mathrm{SA}-\mathrm{Vb} 1^{\top}\left(=\mathrm{JCM} 12946^{\top}=\mathrm{DSM} 18441^{\top}\right)$.
\end{abstract}

Chott el Gharsa (also known as Chott Gharsa or Chott el Rharsa) is one of several dry salt lakes located in the Tunisian Sahara. The lake is $10-25 \mathrm{~m}$ below sea level (Swezey et al., 1999) and represents an important local source of salt. The salt composition is similar to that of concentrated ocean water, making these lakes thallassohaline even though they are located in a desert (Kbir-Ariguib et al., 2001). Other than early work on Halobacterium species (Pfeifer et al., 1981) and on microbial communities in evaporites such as gypsum (Barbieri et al., 2006;

Abbreviation: CZE, capillary zone electrophoresis

The GenBank/EMBL/DDBJ accession number for the 16S rRNA gene sequence of strain $\mathrm{SA}-\mathrm{Vb} 1^{\top}$ is $\mathrm{AB} 197851$.

Fatty acid profiles of strain $\mathrm{SA}-\mathrm{Vb} 1^{\top}$ and related type strains and detailed 16S rRNA gene sequence similarity and DNA-DNA hybridization results are available as supplementary material with the online version of this paper.
Stivaletta et al., 2006), few microbiological studies have been conducted in the Tunisian chotts. Recently, from samples collected from Tunisian salt lakes, we isolated several halophilic and halotolerant bacteria including strains tentatively affiliated with the genus Virgibacillus Heyndrickx et al. 1998, with type species Virgibacillus pantothenticus, which has 13 species at the time of writing. Here we report the taxonomic description of a moderately halophilic, Gram-positive, rod-shaped bacterium, strain $\mathrm{SA}-\mathrm{Vb} 1^{\mathrm{T}}$, which represents a novel species of the genus Virgibacillus.

Strain $\mathrm{SA}-\mathrm{Vb}^{\mathrm{T}}$ was originally isolated from a mixture of dry sediment and salt crusts collected directly from Chott el Gharsa. The sample was inoculated into ATCC medium $925 \mathrm{HP} 101$ [containing $1 \%(\mathrm{w} / \mathrm{v})$ peptone, $0.1 \%$ yeast extract, $10 \% \mathrm{NaCl}, 0.43 \% \mathrm{MgSO}_{4} \cdot 7 \mathrm{H}_{2} \mathrm{O}, 0.2 \% \mathrm{NaNO}_{3}$, $\mathrm{pH}$ 7.2] and incubated at $30{ }^{\circ} \mathrm{C}$. Pure cultures were 
obtained by three successive single colony isolations. The following strains showing $16 \mathrm{~S}$ rRNA gene sequence similarity of approximately $\geqslant 97 \%$ to the novel isolate were used in DNA-DNA hybridization and complementary tests: Virgibacillus marismortui DSM $12325^{\mathrm{T}}$ (Arahal et al., 1999; Heyrman et al., 2003), Virgibacillus olivae DSM $18098^{\mathrm{T}}$ (Quesada et al., 2007), Oceanobacillus picturae DSM $14867^{\mathrm{T}}$ (Heyrman et al., 2003; Lee et al., 2006), Virgibacillus carmonensis DSM $14868^{\mathrm{T}}$, Virgibacillus necropolis DSM $14866^{\mathrm{T}}$ (Heyrman et al., 2003), Virgibacillus halodenitrificans DSM $10037^{\mathrm{T}}$ (Denariaz et al., 1989) and Virgibacillus proomii DSM $13055^{\mathrm{T}}$ (Heyndrickx et al., 1999).

The strains were characterized phenotypically using several common tests. ATCC medium 925 HP 101 with addition of $\mathrm{NaCl}$ up to $30 \%(\mathrm{w} / \mathrm{v})$ was applied to determine the optimal $\mathrm{NaCl}$ concentration for growth. Other tests that were conducted using conventional methods included Gram reaction, acid-fast staining, motility, endospore observation (Doetsch, 1981), anaerobic growth, nitrate reduction, enzyme activities (catalase, urease, phenylalanine deaminase, oxidase) and hydrolysis of starch, aesculin, gelatin and casein (Smibert \& Krieg, 1981). The ability of the bacteria to use single carbon sources was tested using Biolog GP microplates following the instructions of the manufacturer (Garland \& Mills, 1991). Acid production from carbohydrates, nitrate reduction and hydrolysis of some polymers were determined using API 50CH and API 20 CE kits (bioMérieux). In all these tests at $30{ }^{\circ} \mathrm{C}$, strains $\mathrm{SA}-\mathrm{Vb} 1^{\mathrm{T}}$ and DSM $12325^{\mathrm{T}}$ were cultured optimally in media supplemented with $10 \% \mathrm{NaCl}$; similarly, strains DSM $10037^{\mathrm{T}}$, DSM $14866^{\mathrm{T}}$, DSM $14867^{\mathrm{T}}$ and DSM $14868^{\mathrm{T}}$ were cultured with $7 \% \mathrm{NaCl}$ and strain DSM $13055^{\mathrm{T}}$ was cultured in DSM medium 1 without $\mathrm{NaCl}$ ( $0.5 \%$ peptone, $0.3 \%$ meat extract, trace $\mathrm{MnSO}_{4} \cdot \mathrm{H}_{2} \mathrm{O}, \mathrm{pH} 7.0$; Heyndrickx et al., 1999).

Phenotypic characteristics of strain $\mathrm{SA}-\mathrm{Vb} 1^{\mathrm{T}}$ are shown in the species description. Several physiological and biochemical properties are compared with related species in Table 1. Strain $\mathrm{SA}-\mathrm{Vb} 1^{\mathrm{T}}$ was distinguished from the closely related strain V. olivae DSM $18098^{\mathrm{T}}$ in its halophilism and $\mathrm{NaCl}$ range for growth (0.5-25\% compared with 0-20\%), in colony morphology and in the range of temperature for growth $\left(10-50{ }^{\circ} \mathrm{C}\right.$ compared with $\left.20-45{ }^{\circ} \mathrm{C}\right)$ and from both $V$. olivae DSM $18098^{\mathrm{T}}$ and $V$. marismortui DSM $12325^{\mathrm{T}}$ in its inability to reduce nitrate to nitrite and its hydrolysis of Tween 80 .

Cellular fatty acids of strain $\mathrm{SA}-\mathrm{Vb}^{\mathrm{T}}{ }^{\mathrm{T}}$ were determined using the Microbial Identification System (MIDI) using an HP6890 GC (Hewlett Packard) (Sasser, 2001). The major fatty acids detected in strain $\mathrm{SA}-\mathrm{Vb}^{\mathrm{T}}$ were iso- $\mathrm{C}_{14: 0}$ $(4.8 \%)$, iso- $\mathrm{C}_{15: 0}(33.3 \%)$, anteiso- $\mathrm{C}_{15: 0}(29.2 \%), \mathrm{C}_{16: 0}$ (3.9\%), iso- $\mathrm{C}_{16: 0}(5.9 \%), \mathrm{C}_{16: 1} \omega 11 c(1.8 \%), \mathrm{C}_{16: 1} \omega 7 c$ alcohol (1.9\%), iso- $\mathrm{C}_{17: 0}(6.6 \%)$ and anteiso- $\mathrm{C}_{17: 0}$ $(9.8 \%)$. Acids $\mathrm{C}_{15: 0}, \mathrm{C}_{18: 0}$ and $\mathrm{C}_{18: 1} \omega 9 \mathrm{c}$ found in strain V. olivae $\mathrm{E}_{30} 8^{\mathrm{T}}$ (Quesada et al., 2007) were not detected in strain $\mathrm{SA}-\mathrm{Vbl}^{\mathrm{T}}$. The fatty acid profile of isolate $\mathrm{SA}-\mathrm{Vbl}^{\mathrm{T}}$ was also qualitatively and quantitatively different from that of strain V. marismortui DSM $12325^{\mathrm{T}}$ (Vreeland et al., 2006) (see Supplementary Table S1 available in IJSEM Online).

In order to determine other chemotaxonomic properties of strain $\mathrm{SA}-\mathrm{Vb} 1^{\mathrm{T}}$, cell-wall peptidoglycan was determined by HPTLC and HPLC (Komagata \& Suzuki, 1987), quinone analysis was done by HPLC according to Nishijima et al. (1997) and polar lipids were examined by TLC (Komagata \& Suzuki, 1987). Strain $\mathrm{SA}-\mathrm{Vb}^{\mathrm{T}}$ possessed meso-diaminopimelic acid in the cell-wall peptidoglycan. The predominant quinone detected was MK-7 ( 100\%). The major polar lipids were phosphatidylglycerol, diphosphatidylglycerol and phosphatidylethanolamine; two unknown phospholipids were present as minor components (Table 1). These chemotaxonomic properties are commonly found in other members of genus Virgibacillus (Heyndrickx et al., 1998, 1999; Arahal et al., 1999, 2000; Heyrman et al., 2003). The genomic DNA G + C content of strain $\mathrm{SA}-\mathrm{Vb} 1^{\mathrm{T}}$ was determined by capillary zone electrophoresis (CZE) (Fraga et al., 2002; Hua \& Naganuma, 2007). Briefly, highly purified genomic DNAs were enzymically hydrolysed into nucleosides (Tamaoka \& Komagata, 1984; Mesbah et al., 1989). Nucleosides were then eluted in an alkaline phosphate buffer system, separated and quantitatively detected by a CAPI-3300 multichannel CZE (Otsuka Electronics). The analysis resulted in a $\mathrm{G}+\mathrm{C}$ content of $37.4 \mathrm{~mol} \%$ for strain SA$\mathrm{Vb}^{\mathrm{T}}$ (Hua \& Naganuma, 2007) compared with 40.7 and $33.4 \mathrm{~mol} \%$, respectively, for $V$. marismortui DSM $12325^{\mathrm{T}}$ and V. olivae DSM $18098^{\mathrm{T}}$ (Arahal et al., 1999; Quesada et al., 2007) (Table 1).

Genomic DNA was extracted from stationary phase cultures according to the protocol of Wilson (1995). The $16 \mathrm{~S}$ rRNA gene was amplified by the protocol of DeLong (1992). A nearly full-length sequence (1564 bp) of the $16 \mathrm{~S}$ rRNA gene was obtained using a BigDye Terminator ready reaction cycle sequencing kit. Separation of bases was carried out on a 3730xl DNA analyser (Applied Biosystems). Related sequences were identified by normal BLAST search on public databases (GenBank\EMBL\DDBJ) using the FASTA program (Pearson \& Lipman, 1988). All sequences were aligned with CLUSTAL_X software v. 1.83 (Thompson et al., 1997) and checked manually. Phylogeny was inferred using treeing programs constructed with the neighbour-joining, minimum evolution and maximumparsimony methods in MEGA 3.1 (Kumar et al., 2004) and compared with those inferred by using the SEQBOOT, DNADIST, DNAMLK and CONSENSE programs of the PHYLIP package v. 3.61 (Felsenstein, 2004) through 100-1000 replications. The neighbour-joining tree (Fig. 1) is displayed since it showed a topology similar to all other trees and had high bootstrap values (Page, 1996). The $16 \mathrm{~S}$ rRNA gene sequence of strain $\mathrm{SA}-\mathrm{Vb} 1^{\mathrm{T}}$ was very similar to those of V. marismortui $123^{\mathrm{T}}$ and V. olivae $\mathrm{E}_{30} 8^{\mathrm{T}}$ (99.7 and $99.4 \%$ similarity, respectively; Supplementary Table S2), 
Table 1. Differential characteristics of the novel isolate and type strains of related species

Strains: 1, strain SA-Vb1 ${ }^{\mathrm{T}}$ (data from this study); 2, V. olivae $\mathrm{E}_{30} 8^{\mathrm{T}}$ (data from Quesada et al., 2007); 3, V. marismortui DSM 12325 ${ }^{\mathrm{T}}$ (unless indicated, data from Arahal et al., 1999; Heyrman et al., 2003); 4, V. proomii DSM 13055 ${ }^{\mathrm{T}}$ (Heyndrickx et al., 1999); 5, V. carmonensis DSM 14868 (Heyrman et al., 2003); 6, V. halodenitrificans DSM 10037 (Denariaz et al., 1989; Yoon et al., 2004); 7, O. picturae DSM 14867 ${ }^{\mathrm{T}}$ (Heyrman et al., 2003; Lee et al., 2006); 8, V. necropolis DSM $14866^{\mathrm{T}}$ (Heyrman et al., 2003); 9, V. dokdonensis DSW-10 ${ }^{\mathrm{T}}$ (Yoon et al., 2005); 10, V. chiguensis NTU$101^{\mathrm{T}}$ (Wang et al., 2008). +, Positive; -, negative; w, weak; v, variable; ND, no data available. All strains are Gram-positive, rod-shaped, motile and spore-forming and are positive for catalase, oxidase and hydrolysis of casein.

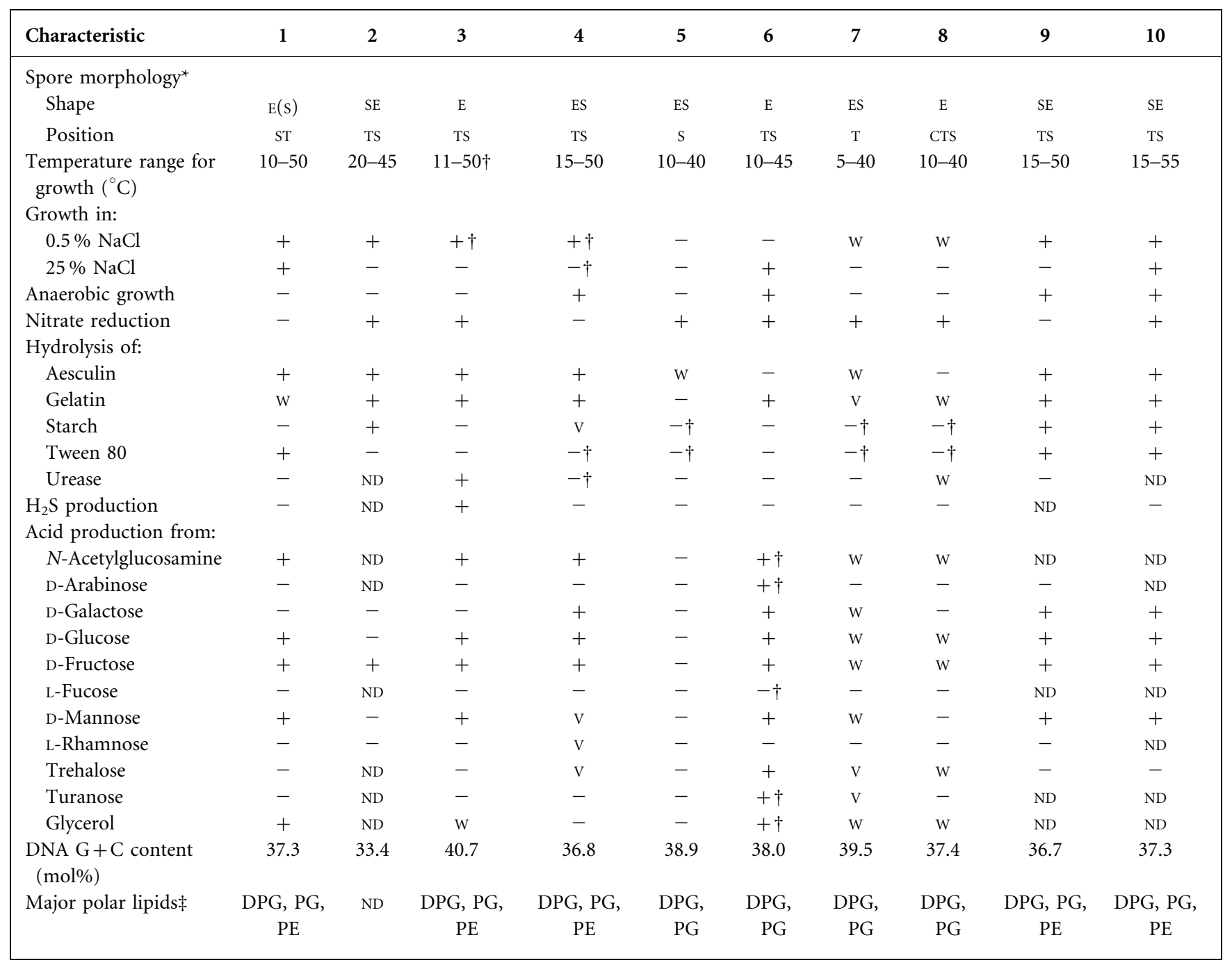

*Shape: E, ellipsoidal; s, spherical. Position: C, central; s, subterminal; T, terminal.

$\dagger$ Data obtained in this study.

‡DPG, Diphosphatidylglycerol; PE, phosphatidylethanolamine; PG, phosphatidylglycerol.

which formed a lineage distinct from all other species (96$98 \%$ sequence similarity; Supplementary Table S2) in phylogenetic trees constructed by different algorithms. The data indicate that strain $\mathrm{SA}_{-}-\mathrm{Vb}^{\mathrm{T}}$ should be classified as a member of the genus Virgibacillus (Stackebrandt \& Goebel, 1994; Stackebrandt et al., 2002).

DNA-DNA hybridization between strain $\mathrm{SA}-\mathrm{Vbl}^{\mathrm{T}}$ and phylogenetically related strains was done by applying the DIG non-radioactive nucleic acid labelling and detection system (Roche Molecular Biochemicals). DIG-11-dUTPlabelled ssDNAs of the target strain were hybridized with reference ssDNAs immobilized on positively charged nylon filter membranes (Brown, 1995) using the DIG-High Prime DNA Labelling, Detection Starter kit II and DIG Wash and block buffer set (Roche Molecular Biochemicals) following the manufacturer's instructions. Chemiluminescent density of hybrids was detected using the VersaDoc Imaging System model 5000 and analysed with Quantity One software v. 4.4 (Bio-Rad). Hybridizations were performed 


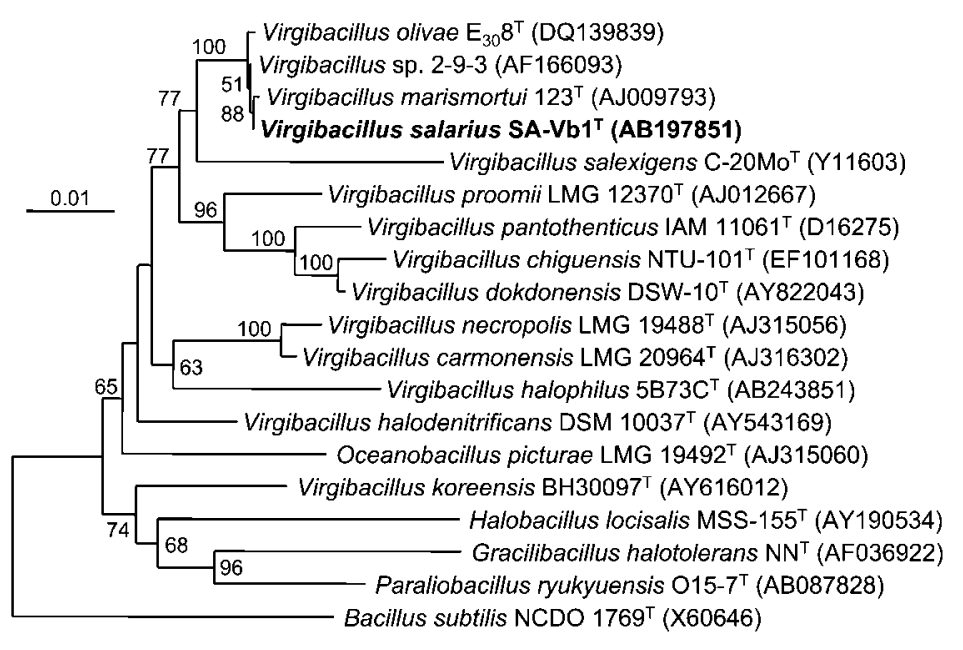

Fig. 1. Neighbour-joining phylogenetic tree showing positions of strain $\mathrm{SA}-\mathrm{Vb} 1^{\top}$ and species of the genus Virgibacillus and other related bacteria based on 16S rRNA gene sequences. Bootstrap values (percentages of 1000 replications) $>50 \%$ are shown at nodes. Bar, 0.01 nucleotide substitutions per site. at least three times and means were calculated. The DNADNA relatedness of strain $\mathrm{SA}-\mathrm{Vbl}^{\mathrm{T}}$ to strains $V$. marismortui DSM $12325^{\mathrm{T}}$ and V. olivae DSM $18098^{\mathrm{T}}$ was 39.9 and $5.1 \%$, respectively; hybridization values with other related strains $O$. picturae DSM $14867^{\mathrm{T}}(22.3 \%), V$. carmonensis DSM $14868^{\mathrm{T}}(23.1 \%)$, V. halodenitrificans DSM $10037^{\mathrm{T}}(21.1 \%)$, V. necropolis DSM $14866^{\mathrm{T}}(18.3 \%)$ and $V$. proomii DSM $13055^{\mathrm{T}}(21.6 \%)$ were also lower than the level conventionally accepted for species delineation (Wayne et al., 1987; Stackebrandt et al., 2002) (Supplementary Table S2).

Strain $\mathrm{SA}-\mathrm{Vb}^{\mathrm{T}}$ shares the common phenotypic, chemotaxonomic and genotypic characteristics of species of the genus Virgibacillus but it is different from existing species. Therefore it is proposed to represent a novel species of the genus, named Virgibacillus salarius sp. nov.

\section{Description of Virgibacillus salarius sp. nov.}

Virgibacillus salarius (sa.la'ri.us. L. masc. adj. salarius of or belonging to salt).

Rod-shaped, Gram-positive, motile cells, 0.6-0.9 $\times 1.8$ $3.5 \mu \mathrm{m}$ (Fig. 2). Cells occur singly, in pairs or as short chains. Endospores are spherical or ellipsoidal and are located in a subterminal or terminal position of swollen sporangia. Colonies are circular and convex with erose or slightly filamentous margins, opaque and white in colour, $2.0-2.5 \mathrm{~mm}$ in diameter after $48 \mathrm{~h}$ at $30-35{ }^{\circ} \mathrm{C}$ on solid medium containing $10 \% \mathrm{NaCl}$. Halophilic; grows weakly at $0.5 \% \mathrm{NaCl}$ and does not grow in medium without $\mathrm{NaCl}$. Growth occurs optimally at $30-35{ }^{\circ} \mathrm{C}, 7-10 \%(\mathrm{w} / \mathrm{v}) \mathrm{NaCl}$ and around $\mathrm{pH}$ 7.5. Ranges for growth are $10-50{ }^{\circ} \mathrm{C}, 0.5-$ $25 \% \mathrm{NaCl}$ and $\mathrm{pH} 5.5-10$. Growth does not occur under anaerobic conditions and nitrate is not reduced to nitrite. Tests for catalase, oxidase and gelatinase are positive. Tests for acid-fast staining, phenylalanine deaminase, tryptophan deaminase, arginine dihydrolase and urease are negative. Tweens 40 and 80, casein and aesculin are hydrolysed. Starch is not hydrolysed. $\mathrm{H}_{2} \mathrm{~S}$ and indole are not produced. Acid is produced from D-glucose, D-fructose, D-mannose,
$\mathrm{N}$-acetylglucosamine, arbutin, maltose, D-tagatose, glycerol, salicin and cellobiose. Acid is not produced from DL-arabinose, DL-xylose, D-galactose, L-rhamnose, inositol, D-mannitol, sucrose, trehalose or melibiose. The following substrates are used as single carbon sources: Tweens 40 and 80, $\mathrm{N}$-acetyl-D-glucosamine, D-fructose, D-mannose, gentiobiose, $\alpha$-ketobutyric acid, $\alpha$-ketoglutaric acid, uridine and thymidine. The major menaquinone is MK-7. Cell-wall peptidoglycan contains meso-diaminopimelic acid. Phosphatidylglycerol, diphosphatidylglycerol, phosphatidylethanolamine and two other unknown phospholipids are cellular polar lipids. Fatty acids are iso- $\mathrm{C}_{15: 0}$ and anteiso- $\mathrm{C}_{15: 0}$ (major components) and iso- $\mathrm{C}_{14: 0}, \mathrm{C}_{16: 0}$, iso- $\mathrm{C}_{16: 0}, \mathrm{C}_{16: 1} \omega 11 c, \mathrm{C}_{16: 1} \omega 7 c$ alcohol, iso- $\mathrm{C}_{17: 0}$ and anteiso- $\mathrm{C}_{17: 0}$. The DNA G+C content of the type strain is $37.3 \mathrm{~mol} \%$ (determined by CZE).

The type strain, SA-Vb1 ${ }^{\mathrm{T}}\left(=\mathrm{JCM} 12946^{\mathrm{T}}=\mathrm{DSM} 18441^{\mathrm{T}}\right)$, was isolated from a salt crust collected from Chott el Gharsa, Tunisia.

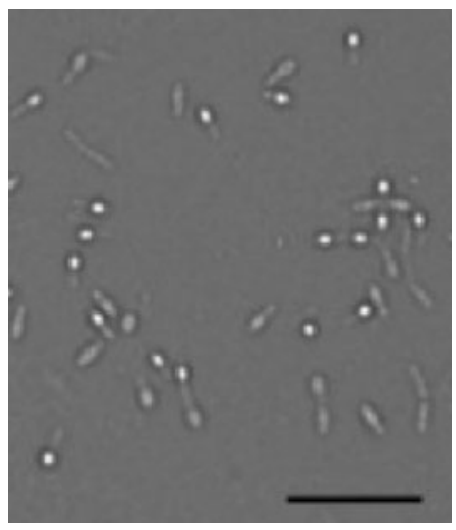

Fig. 2. Phase-contrast micrograph of cells of strain $S A-V b 1^{\top}$. Bar, $5 \mu \mathrm{m}$. 


\section{Acknowledgements}

We thank the Alliance for Research on North Africa, University of Tsukuba, Japan, for their help in sample collection. Part of this work was supported by a Grant-in-Aid for Scientific Research (17657032) from the Japan Society for the Promotion of Science.

\section{References}

Arahal, D. R., Marquez, M. C., Volcani, B. E., Schleifer, K. H. \& Ventosa, A. (1999). Bacillus marismortui sp. nov., a new moderately halophilic species from the Dead Sea. Int J Syst Bacteriol 49, 521-530.

Arahal, D. R., Marquez, M. C., Volcani, B. E., Schleifer, K. H. \& Ventosa, A. (2000). Reclassification of Bacillus marismortui as Salibacillus marismortui comb. nov. Int J Syst Evol Microbiol 50, 1501-1503.

Barbieri, R., Stivaletta, N., Marinangeli, L. \& Ori, G. G. (2006). Microbial signatures in sabkha evaporite deposits of Chott el Gharsa (Tunisia) and their astrobiological implications. Planet Space Sci 54, 726-736.

Brown, T. (1995). Dot and slot blotting of DNA. In Short Protocols in Molecular Biology, 3rd edn, pp. 2.33-2.35. Edited by F. M. Ausubel, R. Brent, R. E. Kingston, D. D. Moore, J. G. Seidman, J. A. Smith \& K. Struhl. Chichester: Wiley.

DeLong, E. F. (1992). Archaea in coastal marine environments. Proc Natl Acad Sci U S A 89, 5685-5689.

Denariaz, G., Payne, W. J. \& Gall, J. L. (1989). A halophilic denitrifier, Bacillus haldenitrificans sp. nov. Int J Syst Bacteriol 39, 145-151.

Doetsch, R. N. (1981). Determinative methods of light microscopy. In: Manual of Methods for General Bacteriology, pp. 21-33. Edited by P. Gerhardt, R. G. E. Murray, R. N. Costilow, E. W. Nester, W. A. Wood, N. R. Krieg \& G. H. Phillips. Washington, DC: American Society for Microbiology.

Felsenstein, J. (2004). PHYLIP (Phylogeny Inference Package) version 3.6. Distributed by the author. Department of Genome Sciences, University of Washington, Seattle, USA.

Fraga, M. F., Uriol, E., Diego, L. B., Berdasco, M., Esteller, M., Canal, M. J. \& Rodriguez, R. (2002). High-performance capillary electrophoretic method for the quantification of 5-methyl 2'-deoxycytidine in genomic DNA: application to plant, animal and human cancer tissues. Electrophoresis 23, 1677-1681.

Garland, J. L. \& Mills, A. L. (1991). Classification and characterization of heterotrophic microbial communities on the basic of patterns of community-level sole-carbon-source utilization. Appl Environ Microbiol 57, 2351-2359.

Heyndrickx, M., Lebbe, L., Kersters, K., De Vos, P., Forsyth, G. \& Logan, N. A. (1998). Virgibacillus: a new genus to accommodate Bacillus pantothenticus (Proom and Knight 1950). Emended description of Virgibacillus pantothenticus. Int J Syst Bacteriol 48, 99-106.

Heyndrickx, M., Labbe, L., Kersters, K., Hoste, B., De Wachter, R., De Vos, P., Forsyth, G. \& Logan, N. A. (1999). Proposal of Virgibacillus proomii sp. nov. and emended description of Virgibacillus pantothenticus (Proom and Knight 1950) Heyndrickx et al. 1998. Int J Syst Bacteriol 49, 1083-1090.

Heyrman, J., Logan, N. A., Busse, H.-J., Balcaen, A., Lebbe, L., Rodriguez-Diaz, M., Swings, J. \& De Vos, P. (2003). Virgibacillus carmonensis sp. nov., Virgibacillus necropolis sp. nov. and Virgibacillus picturae sp. nov., three novel species isolated from deteriorated mural paintings, transfer of the species of the genus Salibacillus to Virgibacillus as Virgibacillus marismortui comb. nov. and Virgibacillus salexigens comb. nov., and emended description of the genus Virgibacillus. Int J Syst Evol Microbiol 53, 501-511.
Hua, N.-P. \& Naganuma, T. (2007). Application of CE for determination of DNA base composition. Electrophoresis 28, 366-372.

Kbir-Ariguib, N., Chehimi, D. B. H. \& Zayani, L. (2001). Treatment of Tunisian salt lakes using solubility phase diagrams. Pure Appl Chem 73, 761-770.

Komagata, K. \& Suzuki, K. (1987). Lipid and cell wall analysis in bacterial systematics. Methods Microbiol 19, 161-207.

Kumar, S., Tamura, K. \& Nei, M. (2004). MEGA3: integrated software for molecular evolutionary genetics analysis and sequence alignment. Brief Bioinform 5, 150-163.

Lee, J.-S., Lim, J.-M., Lee, K. C., Lee, J.-C., Park, Y.-H. \& Kim, C.-J. (2006). Virgibacillus koreensis sp. nov., a novel bacterium from a salt field, and transfer of Virgibacillus picturae to the genus Oceanobacillus as Oceanobacillus picturae comb. nov. with emended descriptions. Int J Syst Evol Microbiol 56, 251-257.

Mesbah, M., Premachandran, U. \& Whitman, W. B. (1989). Precise measurement of the $\mathrm{G}+\mathrm{C}$ content of deoxyribonucleic acid by highperformance liquid chromatography. Int J Syst Bacteriol 39, 159-167.

Nishijima, M., Araki-Sakai, M. \& Sano, H. (1997). Identification of isoprenoid quinones by frit-FAB liquid chromatography-mass spectrometry for the chemotaxonomy of microorganisms. J Microbiol Methods 28, 113-122.

Page, R. D. M. (1996). TreeView: an application to display phylogenetic trees on personal computers. Comput Appl Biosci 12, 357-358.

Pearson, W. R. \& Lipman, D. J. (1988). Improved tools for biological sequence comparison. Proc Natl Acad Sci U S A 85, 2444-2448.

Pfeifer, F., Weidinger, G. \& Goebel, W. (1981). Characterization of plasmids in halobacteria. J Bacteriol 145, 369-374.

Quesada, T., Aguilera, M., Morillo, J. A., Ramos-Cormenzana, A. \& Monteoliva-Sanchez, M. (2007). Virgibacillus olivae sp. nov., isolated from waste wash-water from processing of Spanish-style green olives. Int J Syst Evol Microbiol 57, 906-910.

Sasser, M. (1990). Identification of bacteria by gas chromatography of cellular fatty acids, MIDI Technical Note 101. Newark, DE: MIDI Inc.

Smibert, R. M. \& Krieg, N. R. (1981). General characterization. In Manual of Methods for General Bacteriology, pp. 409-443. Edited by P. Gerhardt, R. G. E. Murray, R. N. Costilow, E. W. Nester, W. A. Wood, N. R. Krieg \& G. B. Phillips: Washington, DC: American Society for Microbiology.

Stackebrandt, E. \& Goebel, B. M. (1994). Taxonomic note: a place for DNA-DNA reassociation and $16 \mathrm{~S}$ rRNA sequence analysis in the present species definition in bacteriology. Int J Syst Bacteriol 44, 846-849.

Stackebrandt, E., Frederiksen, W., Garrity, G. M., Grimont, P. A. D., Kämpfer, P., Maiden, M. C. J., Nesme, X., Rosselló-Mora, R., Swings, J. \& other authors (2002). Report of ad hoc committee for the re-evaluation of the species definition in bacteriology. Int J Syst Evol Microbiol 52, 1043-1047.

Stivaletta, N., Barbieri, R., Bosco, M., Picard, C., Ori, G. G. \& Marinangeli, L. (2006). Microbial communities from continental sabkhas of southern Tunisia: terrestrial analogues of Mars evaporite environments. In Abstracts of the 37th Lunar and Planetary Science Conference, p. 1608. 13-17 March 2006, League City, TX, USA. http:// www.lpi.usra.edu/meetings/lpsc2006/pdf/1608.pdf

Swezey, C., Lancaster, N., Kocurek, G., Deynoux, M., Blum, M., Price, D. \& Pion, J.-C. (1999). Response of aeolian systems to Holocene climatic and hydrologic changes on the northern margin of the Sahara: a high-resolution record from the Chott Rharsa basin, Tunisia. Holocene 9, 141-147.

Tamaoka, J. \& Komagata, K. (1984). Determination of DNA base composition by reversed-phase high-performance liquid chromatography. FEMS Microbiol Lett 25, 125-128. 
Thompson, J. D., Gibson, T. J., Plewniak, F., Jeanmougin, F. \& Higgins, D. G. (1997). The CLUSTAL_X windows interface: flexible strategies for multiple sequence alignment aided by quality analysis tools. Nucleic Acids Res 25, 4876-4882.

Vreeland, R. H., Rosenzweig, W. D., Lowenstein, T., Satterfield, C. \& Ventosa, A. (2006). Fatty acid and DNA analyses of Permian bacteria isolated from ancient salt crystals reveal differences with their modern relatives. Extremophiles 10, 71-78.

Wang, C. Y., Chang, C. C., Ng, C. C., Chen, T. W. \& Shyu, Y. T. (2008), Virgibacillus chiguensis sp. nov., a novel halophilic bacterium isolated from Chigu, a previously commercial saltern located in southern Taiwan. Int J Syst Evol Microbiol 58, 341-345.

Wayne, L. G., Brenner, D. J., Colwell, R. R., Grimont, P. A. D., Kandler, O., Krichevsky, M. I., Moore, L. H., Moore, W. E. C., Murray, R. G. E. \& other authors (1987). Report of the ad hoc committee on reconciliation of approaches to bacterial systematics. Int J Syst Bacteriol 37, 463-464.

Wilson, K. (1995). Preparation of genomic DNA from bacteria. In Short Protocols in Molecular Biology, 3rd edn, pp. 2.11-2.13. Edited by F. M. Ausubel, R. Brent, R. E. Kingston, D. D. Moore, J. G. Seidman, J. A. Smith \& K. Struhl. Chichester: Wiley.

Yoon, J.-H., Oh, T.-K. \& Park, Y.-H. (2004). Transfer of Bacillus halodenitrificans Denariaz et al. 1989 to the genus Virgibacillus as Virgibacillus halodenitrificans comb. nov. Int J Syst Evol Microbiol 54, 2163-2167.

Yoon, J. H., Kang, S. J., Lee, S. Y., Lee, M. H. \& Oh, T. K. (2005). Virgibacillus dokdonensis sp. nov., isolated from a Korean island, Dokdo, located at the edge of the East Sea in Korea. Int J Syst Evol Microbiol 55, 1833-1837. 